\section{養殖ギンザケにおける肝臓の 類脂肪変性について}

厚田静男 - 小林一裕・酒井正博 - 小林正典 (北里大学水産学部水族病理学教室)

最近，北日本を中心としてギンザケ Oncorhynchus kisutch の養殖がさかんになってきているが, 淡水での種 苗育成時や海中養殖時における細菌性腎臓病 (BKD), せ っそう病などの細菌性疾病の発生もさることながら，栄 養性疾病と考えられる肝蔵障害を主徵候とした疾病も多 く発生している。1986年に三陸沿岸に予いて海中覞殖さ れていたギンザケの異常魚と 1987 年に岩手県下の淡水 責殖場で飼育されていたギンザケ幼您のひえ死魚で剖検 の際, 肝臓の肉腿所見に批いて, 白変, 黄変, 赤変が混 合し，あたか子もザイク模様状になっていた検体が多く の割合で観察された。本報ではこれら肝臟の異常につい て病理組織学的に検討したので, その結果について述べ る。

\section{材料及び方法}

供試魚は 1986 年 6 月に三陸沿岸で海中養殖されてい たギソザケのひん死魚中前述の肝臓所見を呈していたも の 20 険体 (体重約 $2 \mathrm{~kg}$ ) < 1987 年 7 月下岩手県下の 淡水䔔殖場で飼育されていたギンザケ姑魚（体重約 $20 \mathrm{~g}$ ) のひ儿死魚中同様の肝蔵所見を呈した 10 検体を用い た。これら検体の肝蔵は $10 \%$ ホルマリン固定後, 常法 に従い゚ラフィン切片約 $5 \mu$ 老作製し, H.E 染色, チ ルネルゼン染色, 並びにナイル青染色を施した。また肝 葴の一部は固定後, 涷結切片を作製し脂肪染色等を施し た。又, 肝葴の一部は細菌検查及びウイルス検查に供し た。

\section{結果}

\section{外見，剖検所見}

病魚は外見的には特に異常を示さない。剖倹的には鰓 の貧血之肝臓の顕著な色調変化 (白変, 黄変, 赤変の混 合）が認められた。また，体重に対する肝臓重量の割合 は正常魚の $1 \%$ と比較して大きく 2 \% $5 \%$ にもなるもの も観察された。

病理組織学的所見

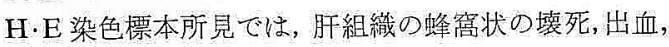
肝細胞の空胞変性, 病栄部に褐色の色素顆粒の沈着がみ

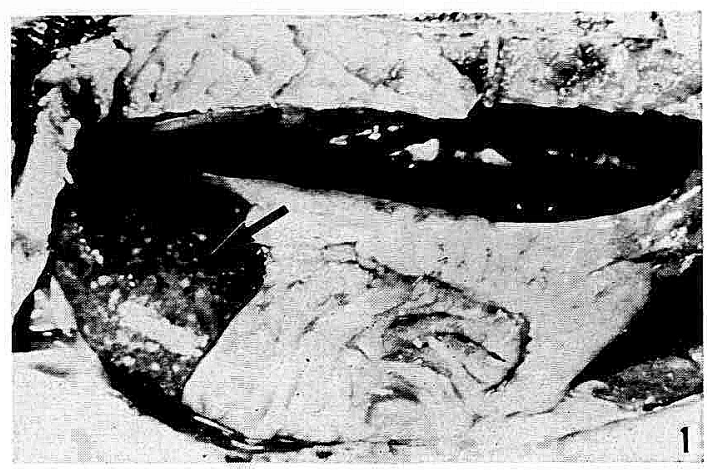

図 1 病魚の剖検所見, 肝臟に顕著な色調変化白变, 黄変, 赤変の混合が認的られ, 矢印肝朢は肥 大している.

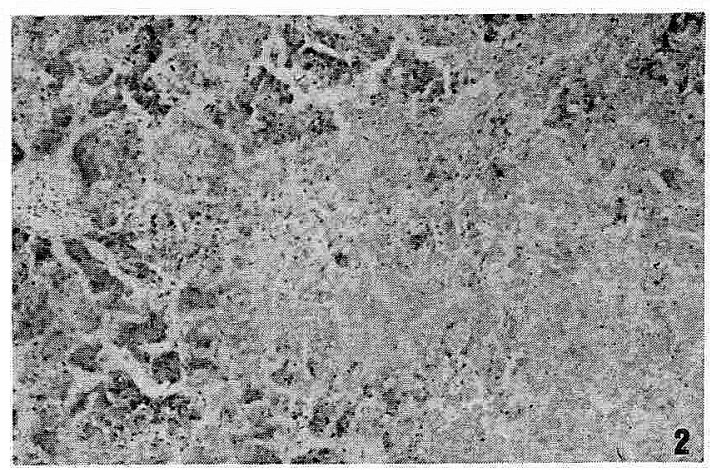

図 2 病瀂肝臟の組織像，肝細胞は壊死，空胞変性 を起こし，正常部はほとんど無く，脂肪染色 では強度の脂肪浸潤や類脂肪の沈等着が钼察 される。

とめられ，脂肪染色及び特殊染色所見に和いては強度の 脂肪浸潤，類脂肪の沈着及び若干ではあるがセロイドの 沈着る認められた。

細菌及びウイルス検査結果

いずれの検体からも原因と考学られる細菌及びウイル スを分離しえなかった。

考察

以上の結果から，今回用いた海中養殖ギソザタ及び淡 水養殖ギンザケ幼魚で観察された肝臓の異常は, 類脂肪 変性定と判断された。魚煩の肝缄における脂肪変性につ いては，多くの報告があり，大西洋サケについて

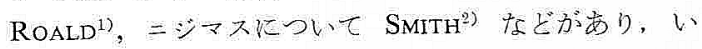
ずれ子䭒料中の過酸化物とビタミン E の欠乏が要因と して論じれてい尚。宗た MoCCIA ${ }^{32}$ はニジスに 
おいて, 同様にビタミン $\mathrm{E}$ などの抗酸化剈と酸化魚油 の影響について報告している。

本報告に和いて，使用した淡水養殖ギンザヶは，市販 のペレットで飼育されており，また海中養殖ギンザケは， 冷凍イワシを主体とした䬣で飼育されたものである。淡 水養殖に执いて使用されていたペレットについて, 調查 したところ，その中に含まれる過酸化物が多く、飼料原 料として使用した，魚粉が問題であったのではないかと 考えられた。また海中養殖において使用されていた冷凍 イワシについては，その過酸化物価は不明であった。さ らに, 飭料の質以外飞問題となることは, これら検体と なったギンザケが，低水温期に高い給慨率（乾燥換算で
3〜4\%) で飼育されたことであると考兄られる。このこ とから今回, 観察された肝臓異常の原因を推察すると, 低水温期に過酸化物の多い餌料の過給慨と，とれに対応 する抗酸化剂としての，ビタミン E 不足が考兄られる。

\section{文献}

1) Roald S. O. (1976): Nord. Vet. Med., 28, 243-249. 2) Sмiтн C. E. (1979): J. Fish. Dis. 2, 429-437. 3) Moccia R. D. et al. (1984): J. Fish. Dis. 7, 269-282. 